\title{
Definition of Customs Offences in International Law
}

\section{Sergey Ovchinnikov}

\author{
Far Eastern Federal University, Vladivostok, Russian Federation
}

Email: sovchinn@yandex.ru

\section{Doi:10.5901/mjss.2015.v6n3s6p219}

\begin{abstract}
Customs offenses pose a serious threat to the world legal order. Establishment of responsibility for them in international law demands accuracy and formal definiteness. Definition of a customs offense is necessary for consistent approach elaboration to them, establishment of customs authorities' jurisdictions, ensuring the assistance between customs authorities of different countries. The problem of customs offenses definition includes three aspects: differentiation of customs offenses from other offenses; differentiation of customs crimes and customs offenses; differentiation of international crimes and crimes of international character. The definition of customs offenses in international law is carried out at the common, regional and bilateral levels. As a rule, the regional regulation is carried out within Customs unions that have the consistent approach to customs offenses. And this regulation significantly varies on degree of detail. The analysis of international law acts shows the following features of a customs offense: the material - in any case these acts are connected with conveyance of goods across the customs border; the formal - they represent violation of customs legislation; and the procedural - production on these offenses is referred to customs authorities maintenance. The most widespread and dangerous customs crime is smuggling. Smuggling in international legal acts is considered as a crime when they establish the duty of States to qualify these acts in national legislation in a proper way. Also there is another approach when an international law act defines smuggling as an offense and gives the states an opportunity to qualify these acts either as a crime, or as an administrative offense. Merits and demerits of each of the mentioned approaches are noted. The article defines the international customs offense as the act encroaching on the established by the international legislation order relating to the conveyance of goods and other subjects across the customs border that causes administrative or criminal liability according to the national legislation.
\end{abstract}

Keywords: international customs law, international criminal law, customs offense, customs crime, smuggling.

\section{Introduction}

In the modern period the international law is growing in importance that is defined by the aim to ensure peace and international security, development of the international assistance, strengthening of integration processes. We pay our close attention to one of the public international law branches, the international customs law, that represents the system of norms and principles governing the relations between the states and the international intergovernmental organizations on the course of their assistance in customs affairs, in subjects, goods and vehicles conveyance regulation across the customs border from. The international law carries out the law-enforcement function which is expressed in the revelation and suppression of the international crimes and crimes of international character. The protective function of the international customs law consists in protection of vital interests of the international community as a whole and each state separately, of society and person, in maintenance of the world law order by establishment of the ban and restrictions on conveyance of objects representing a danger to values recognized by the world community, and also by determination of customs crimes and other offenses (Ovchinnikov, S. 2013-2). According to the general criminal law principles of the international law, the definition of a crime must be accurately explained and must not be used by analogy (International Criminal Court, 1998, Art. 22).

\section{The Definition of Customs Offenses under General International Law}

The main international law act defining customs offenses is the International Convention on the Simplification and Harmonization of Customs Procedures (Kyoto Convention, 1973) and its Annex H (World Customs Organization, 19992). This Annex establishes the standards and recommendations on the practical application that the national customs administrations most follow during the investigation and qualification of customs offenses, the arrest or detention of goods and vehicles, etc.

The definition of a customs offense is necessary for the consistent approach elaboration to them, establishment of 
customs authorities' jurisdictions, ensuring the co-operation between customs authorities of different countries. In the Annex $\mathrm{H}$ of the Kyoto Convention the customs offense is defined as any violation or attempt of the customs legislation violation. This quite common and laconic definition doesn't list the concrete types of the customs offenses because, as noted in the Standard Rule 2 of the Kyoto Convention Annex $\mathrm{H}$, the national legislation defines the customs offenses and fixes the conditions under which they can be investigated, established and, if necessary, be an object of the administrative settlement.

The International Convention on Mutual Administrative Assistance in Prevention, Investigation and Suppression of the customs offenses. (The Nairobi Convention, 1977) gives the same definition of a customs offense (World Customs Organization, 1977). At the same time, such customs offenses as the deception of customs and smuggling are marked in it. The deception of customs means a customs offense when the person deceives customs and thus partially or completely deviates from payment of import or export duties and taxes, or avoids the established by the customs legislation ban or restrictions, or receives other benefits in situation of infringing the customs legislation. Smuggling means the deception of customs consisting in conveyance of goods across the customs border in any hidden form, i.e. smuggling is considered as a kind of the deception of customs. The Commentaries of the World Customs Organization to the Nairobi Convention (World Customs Organization, 1999) defines more precisely that the definition of smuggling that is given in it concerns not only the cases when goods are hidden to avoid the customs control, but also the cases when goods, though they are not hidden, but are not properly declared. Smuggling covers all ways of conveyance of goods, including the international mails.

\section{The Definition of Customs Offenses in the Regional International Law}

The definition of customs offenses in the international law is carried out at the common, regional and bilateral levels. As a rule, the regional regulation is carried out within Customs unions that have the consistent approach to customs offenses. And this regulation significantly varies on degree of detail: from the minimal in the European Union Modernised Customs Code to the maximal in the General Customs Act of the Customs Union of the Cooperation Council for the Arab States of Customs union of the Gulf (GCC). The European Union Modernised Customs Code in Section 5 of the Chapter 2 obliges the states - members of the union to provide the penalties for improper observance of the customs legislation of the Community. Such sanctions must be effective, proportional and dissuasive (European Union, 2008). The literature notes that sanctions for customs offenses in the European Union are not harmonized, and it even was a matter of dispute of the World Trade Organization dispute settlement body (Weerth, C., 2013). The Customs Code of the Eurasian Customs Union says about the administrative offenses and crimes that they are the administrative offenses on which, according to the legislation of the states that are the member of the Customs Union, the customs authorities conduct an administrative process (carry out the production), and crimes, the production on which is referred to the customs authorities conducting according to the legislation of the states - members of the Customs Union (Eurasian Economic Community, 2009).

The common customs law of the Customs Union of GSS from 2003 differentiates the violations of customs rules and smuggling. Sec. 141 of the Law refers to the violations of customs rules, that are punished with the penalty, the violations while importing, exporting and re - export; the violations during the declaring, transit, storage, temporary import of goods, and also any other.

Sec. 142 of the Law defines smuggling as the conveyance or attempt of the conveyance of goods to the country or from the country infringing the current legislation without payment of the customs duties and taxes, completely or partially, or infringing the ban and restrictions provided by the present Law or other laws.

In particular, as smuggling is considered the conveyance of goods besides the check points and the violation of the routes that are intended for import or export of goods; loading or unloading the vessels and aircrafts out of the proper for this purpose places; the failure to declare goods; the concealment of the conveyed goods in hiding or other, improper for goods, places; release of goods from free zones, duty free shops, customs warehouses and customs areas without the end of customs procedures; providing false, deceptive or counterfeit documents with the purpose to deviate from payment of customs taxes and duties or to avoid the ban and restrictions; transportation or procurement of the forbidden or limited goods without providing proofs of their lawful import; some other acts.

Smuggling assumes the presence of intention and results in the criminal liability. Subjects of responsibility are doers, accomplices, instigators and abettors; owners of smuggled goods; owners of vehicles used for smuggling, and also the drivers of these vehicles involved in smuggling; owners or holders of shops and other places where smuggled goods are stored.

In the considered Law the sanctions for customs offenses are also established. Sanctions include: the penalty estimated depending on the sum of the customs duties, taxes which are due from the goods that are conveyed with the 
violation, or depending on the cost of goods; imprisonment; confiscation of smuggled goods and vehicles that were used for these goods and also other subjects smuggling conveyance. The size of sanctions depends on characteristics of smuggled goods: whether these goods are exempted from payment of the customs duties, taxes, or the high customs duties and taxes are levied from them, or they are the forbidden goods. Respectively the sum of the penalty can be from $10 \%$ to the triple cost of goods or not less double the amount of the due customs duties and taxes. Imprisonment can be settled for a period from one month to three years. Both the penalty and imprisonment can be simultaneously settled. In case of a repeated offense the penalty can be doubled (Ovchinnikov, S. 2013-1).

In Recommendations of the World Customs Organization to the Annex $\mathrm{H}$ of the Kyoto Convention the examples of the national legislation concerning the customs offenses are given. In many countries the obstacle or difficulty at implementation of customs control measures, false accounts or documents relate also to the customs offenses. In those countries where the customs services pursue investigations of the violations concerning illicit drug trafficking, and the violations connected with the failure to pay the value - added taxes at the goods importing, such acts relate to the customs offenses. If competence of the customs service of the country includes the investigations conducting of financial operations, in particular, at implementation of the currency control, then the revealed violations can be also considered as the customs offenses because they are connected with an import and export of goods. In some countries any person which made, on whose initiative was made, or which produced the false documents or documents which are obviously intended for the deception of the customs authorities and which are used in any foreign state, is considered as the person which made a customs offense in the country where these documents were made. It relates to the measures within mutual aid which are specially foreseen in some agreements on providing preferences in trade (World Customs Organization, 1999-3).

It is possible to emphasize the features of a customs offense that are given in the mentioned definitions: the material - in any case these acts are connected with conveyance of goods across the customs border; the formal - they represent violation of customs legislation; and the procedural - production on these offenses is referred to customs authorities maintenance. According to Tulenyov (2012) "the jurisdiction is not a feature of crimes", but in our opinion, it can serve as one of the bases for their classification as the above-stated international legal acts argue.

\section{Construction of a Customs Offense}

According to the Nairobi Convention Preamble, the object of a customs offense is economic, social and tax interests of states, and legitimate interests of trade.

The objective side of customs offenses manifests itself in violation or attempted violations of the customs legislation. This act can be both an action, and an omission. The customs legislation in the International Law Acts is defined differently. The customs legislation in the General Appendix of the Kyoto Convention means a set of the laws and bylaws concerning import, export, movement or storage of goods, the application and execution of which is entrusted directly to the customs service, and the laws and bylaws concerning any standard regulations issued by the customs service within the limits of its competence. The Nairobi Convention defines the customs legislation as all regulations on import, export or transit of goods, established by the law or the subordinate legislation, and which compliance is provided with the customs services. The agreement of CIS countries on cooperation and mutual assistance in customs affairs of April 151994 defines the customs legislation as a set of legal norms of the parties that regulate the import, export and transit of goods, hand luggage and passenger baggage, currency and other types of values, international mailings, customs duties and other payments, exemptions, bans and restrictions, and control of movement of goods through customs borders of the parties (Commonwealth of Independent States, 1994).

The subjective party of a customs offense presupposes an existence of guilt in an act by any person. The Standard Rule 25 of the Annex $\mathrm{H}$ points at it indirectly: in case a customs offense occurs because of force majeure or other circumstances, which are not depended on will of a person concerned, and there is no negligence or intention on deception from his side, sanctions are not imposed, if these facts are established properly to be satisfied by the customs service (World Customs Organization, 1999-2).

\section{Customs Crimes and Misdemeanors (Administrative Offences)}

The customs offenses on degree and character of the public harm are divided into the customs crimes and offenses (the administrative offenses in customs affairs, the violation of the customs rules). This differentiation is carried out in the national legislation and some acts of the Customs Unions. So, the Customs Code of the Eurasian Customs Union defines the customs crimes as crimes the production on which is referred to customs authorities maintenance according to the 
legislation of the states - members of the Customs Union (Eurasian Economic Community, 2009). As the main international legal basis of criminalization of smuggling Sogomonov (2012) considers the Nairobi Convention. However, this Convention does not separate the customs crimes from other customs offenses.

In the theory of the international criminal law two groups of crimes are emphasized: the international crimes and crimes of international character or conventional crimes. The international crimes are the most serious crimes which threaten the world peace, security and well-being, cause a concern of the whole international community. It is genocide, the crimes against humanity, war crimes, aggression. The crimes of international character differ from the international crimes on encroachment objects and degree of their public danger. The crimes of international character in comparison with the international crimes are less socially dangerous acts, encroach on the relations on the international cooperation of the states in various spheres: social and cultural, economic, ecological, business, research, military and technical, legal cooperation, etc.

The terms «transnational, cross-border crimes» are sometimes used to define the crimes of international character. The concept of a transnational crime is given in Sec. 3 of the United Nations Convention against Transnational Organized Crime (2000). The crime has a transnational character, if: a) it is committed in more than one state;

b) it is committed in one state, but the great part of its preparation, planning, and control occurs in other state; c) it is committed in one state, but with the participation of an organized criminal group which carries out the criminal activity in more than one state; or d) it is committed in one state, but its substantial effects take place in other state (UN Office on Drugs and Crime, 2004).

Based on the mentioned features, smuggling is defined as a crime of international character. In scientific literature it is possible to meet and the characteristic of smuggling as an international crime. According to Martsiushevskaya and Ostroga (2012), smuggling can be considered as an international crime because it undermines the key principles of the international law, threatens the international peace and security. It is about smuggling of narcotic and psychotropic substances, the weapon, smuggling of cultural values, endangered species of flora and fauna is also mentioned. However, it is unlikely possible to agree with this position. In the international legal acts the mentioned acts are not recognized as the international crimes, and this recognition is premature. Smuggling itself is not a crime that is under jurisdiction of the International Criminal Court (International Criminal Court, 1998).

The reference of the considered acts to the international crimes will add a little to the existing order, but can complicate the liability procedure.

Smuggling in the international legal acts is defined as a crime when they establish an obligation of the states to qualify these acts in proper way in the national legislation. For example, the United Nations Convention against Illicit Traffic in Narcotic Drugs and Psychotropic Substances obliges the sates- members to recognize an import or export of any drug or any psychotropic substance in defiance of points of the Convention as the criminal offenses according to the legislation (UN Office of Drugs and Crime, 2013). There is another version when the international legal act defines smuggling as an offense and gives the states an opportunity to qualify these acts either as a crime, or as an administrative offense. So, the Convention of UNESCO on the measures directed on prohibition and the prevention of illegal import, export and transfer of ownership of cultural values of 1970 in Sec. 8 establishes that the states- members of the Convention undertake to impose all responsible for violation of the bans, that are foreseen in the Convention, persons the criminal or administrative penalty, in particular, export from the territory of cultural values without the corresponding permission (UNESCO, 1970). Each of the mentioned approaches has merits and demerits. The first version provides the common determination of the considered acts illegality and the level of responsibility. The second version gives a chance to consider national features. To the contrary, the second version does not provide the common determination of the considered acts illegality and the level of responsibility. The first version does not give a chance to consider national features. From our point of view the consistency is more preferable thing, the aspiration to which is found in the international legal acts. So, the Contract on features of criminal and administrative liability for violations of the customs legislation of the Customs Union and the states- members of the Customs union establishes that types of crimes and administrative offenses are defined by the legislation of the parties, and each of the parties undertakes to take measures for making the illegality determination of the customs legislation violations common (Eurasian Customs Union, 2010).

In literature the opinion is expressed that questions of counteraction to smuggling at the interstate level are not subjected to a deep legal regulation and the common act of international legal character is important (Kravtsov is necessary, for R.V., Lisauskayte, V.V., 2006), however, it nothing is mentioned about possible contents of this estimated act. It is represented that the definition of customs offenses and smuggling in the Nairobi Convention has enough for ensuring the consistent approach.

To conclusion of the present article we will pay our attention to the problem of differentiation of customs crimes and 
other crimes of international character. Karpets (1979) has noted the following types of crimes of international character that cause the damage to : 1) peaceful association and normal implementation of the interstate relations (terrorism, stealing of planes, illegal broadcasting, etc.); 2) the international economic and social and cultural development (smuggling, illegal emigration, drug trafficking, falsification of money and securities, etc.); 3) persons, property, moral values (human trafficking, piracy, distribution of pornography, etc.); 4) other crimes of international character (the made onboard aircraft, a gap or defect of a sea cable, no help at the sea, etc.) . It is possible to notice that the classification criterion is not always observed, for example, skyjack and the crimes committed onboard the aircraft.

In contemporary literature there is a transnational environmental crime defined as a kind of smuggling (Elliott L., 2012). The United Nations Office on Drugs and Crime considers an illicit trafficking of drugs, firearms, counterfeit medicines and goods, endangered species of flora and fauna, etc. as transnational crimes (UN Office of Drugs and Crime, 2010). The International legal acts establish bans and restrictions on exports and imports of different items. The general feature of the customs crimes is an infringement of established movement of goods and other items through the customs border. If these bans and restrictions are determined by the international law, in that case they become international crimes. Although, at the level of the common international law it is, as a matter of fact, about the same crime — smuggling, the subjects of which only differ.

\section{Conclusion}

Based on the above, the international customs offense can be defined as an act infringing on established by the international law acts movement of goods and other items across the customs border, involving administrative or criminal liability on the national legislation. The proposed definition seems to contribute to elaboration of an integrated approach to customs offenses in the international law, establishment of customs authority powers, and ensuring assistance between customs authorities of different countries.

\section{References}

Commonwealth of Independent States, (1994). Agreement of CIS countries on cooperation and mutual assistance in customs matters. Retrieved from http://www.consultant.ru/document/cons_doc_LAW_3761/

Elliott, L. (2012). Fighting Transnational Environmental Crime. Journal of International Affairs. Fall/Winter . Vol. 66. № 1.

Eurasian Economic Community, (2009). Customs Code of the Customs Union. Retrieved from http://www.tsouz.ru/Docs/kodeks/ DocumentS/TRANSLATION\%20CUC.pdf

Eurasian Economic Community, (2010). Treaty about the features of criminal and administrative responsibility for violation of the customs legislation of the Customs Union and the states - members of the Customs Union. Retrieved from http://www. tsouz.ru/MGS/MGS11/Pages/P1_50.aspx

European Union (2008). Modernised Customs Code. Regulation (EC) № 450/2008 of the European Parliament and of the Council of 23 April 2008. Official Journal of the European Union L 145, 4.6.2008. Retrieved from http://eur- lex.europa.eu/LexUriServ/LexUri Serv.do?uri=OJ:L:2008:145:0001:0064:En:PDF

International Criminal Court (1998). Rome Statute of the International Criminal Court. United Nations, Treaty Series, vol. 2187, № 38544. Retrieved from http://www.icc-cpi.int/NR/rdonlyres/ADD16852-AEE9-4757-ABE7-9CDC7CF02886/283503/RomeStatut Eng1.pdf

Karpets, I. I. (1979). Crimes of International Character. M.: Jurid. lit.

Kravtsov, R.V., Lisauskayte, V.V. (2006). Contraband in an International Law. Siberian Law Herald. № 3 (30).

Martsiushevskaya E., Ostroga V. (2012). Smuggling as a Crime of International Character: Concept, Characteristics, Qualifications. Customs Scientific Journal CUSTOMS. № 1.

Ovchinnikov, S. (2013-1). Customs Regulation in the Cooperation Council for the Arab States of the Gulf. Middle-East Journal of Scientific Research. V 14. № 7.

Ovchinnikov, S. (2013-2). About Functions of the International Customs Law. Eurasian advocacy. № 2 (3).

Sogomonov, D.K. (2012). The International Legal Bases of the Criminalization of Contraband in the National Criminal Legislation. Scientific Problems of Humanitarian Researches. № 3.

Tulenyov, A.I. (2012). Topical Problems of Terminology and Notions of Crimes of Customs. Vestnik of Nekrasov Kostroma State University. № 5.

UNESCO, (1970). Convention on the Means of Prohibiting and Preventing the Illicit Import, Export and Transfer of Ownership of Cultural Property. Retrieved from http://portal.unesco.org/en/ev.php-URL_ID=13039\&URL_DO=DO_TOPIC\&URL_SECTION=201.html

UN Office on Drugs and Crime, (2004) United Nations Convention against Transnational Organized Crime. New York. Retrieved from http://www.unodc.org/documents/treaties/UNTOC/Publications/TOC\%20Convention/TOCebook-e.pdf

UN Office of Drugs and Crime. (2010). Globalization of Crime: A Transnational Organized Crime Threat Assessment. Vienna. Retrieved from http://www.unodc.org/unodc/en/data-and-analysis/tocta-2010.html 
UN Office of Drugs and Crime, (2013). The International Drug Control Conventions. New York. Retrieved from http://www.unodc. org/documents/commissions/CND/Int_Drug_Control_Conventions/Ebook/The_International_Drug_Control_Conventions_E.pdf

Weerth, C. (2013). Customs Sanctions of the EU-27: A Détailed Analysis and a Preview on the Modernized Customs Code of the EU and the European Union Customs Code. Global Trade and Customs Journal. 2013. Vol. 8, Issue 2.

World Customs Organization, (1977). International convention on mutual administrative assistance for the prevention, investigation and repression of customs offences. Retrieved from http://www.wcoomd.org/en/about-us/legal-instruments/ /media/574B25F13 D9C4D4BA44AB4CD50A967C5.ashx

World Customs Organization, (1999-1). Commentary on International convention on mutual administrative assistance for the prevention, investigation and repression of customs offences. Retrieved from http://www.wcoomd.org/en/about-us/legal-instruments/ /media /574B25F13D9C4D4BA44AB4CD50A967C5.ashx

World Customs Organization, (1999-2). International Convention on the Simplification and Harmonization of Customs Procedures (as amended). Retrieved from http://www.wcoomd.org/en/topics/facilitation/instrument-and-tools/conventions/pf_revised_kyoto_conv / /link.aspx?_id=9418E938104D4DA491E094E68F1F1169\&_z=z

World Customs Organization, (1999- 3). Kyoto Convention Recommendations for Special Applications H, Chapter 1. Customs Offenses. Retrieved from http://online.zakon.kz/Document/?doc_id=30494455\&doc_id2=30494455\#sub_id=1001207163\&sub_id2=300\& sel_link=1001207163 